\title{
Gestcorp: revelação de minha identidade profissional
}

Gestcorp: revelation of my
professional identity

Gesstcorp: la revelación

de mi identiddad profesional

Ynara T. Anseloni dos Santos ${ }^{6}$

A partir das duas últimas décadas do século $\mathrm{XX}$, o mundo vem passando por um processo de transformação de ordem econômica, política e social, ocasionado pela globalização dos mercados e pela revolução tecnológica da informação e da comunicação. A conformação da sociedade em uma rede global dissolve as barreiras temporais, espaciais e geográficas, construindo uma realidade diferente.

A nova ordem mundial desperta novos valores e nova consciência sobre o papel e os direitos de cada um como cidadão e consumidor, passando a exigir mais qualidade dos produtos e serviços das organizações.

Hoje, a responsabilidade das organizações não está mais restrita aos valores econômicos. O aumento da concorrência, agora em nível mundial, faz com que elas reavaliem seus processos de gestão e adotem postura diferente diante da nova configuração da sociedade para se manterem competitivas. Como são sistemas abertos, tornam-se cada vez mais vulneráveis às constantes transformações mundiais.

6 Especialista em Gestão de Processos Comunicacionais (2001) e em Gestão Estratégica em Comunicação Organizacional e Relações Públicas (2006) pela ECA-USP, graduada em Marketing pela Escola de Propagande e Marketing (1992), é gestora de Comunicação da Voith Paper para a América Latina. Foi integrante da Turma 2004B do Gestcorp, tendo defendido a monografia Políticas de comunicação integrada: o poder estratégico das organizações contemporâneas. E.mail: ynara.santos@voith.com. 
Uma vez que as relações sociais ocorrem por meio de processos comunicacionais, é necessário que a Comunicação Empresarial deixe de ser concebida como ferramenta instrumental e funcionalista, em que ações são planejadas para se atingir objetivos pontuais, e se torne $\mathrm{r}$ mediadora entre os agentes sociais, assumindo posição estratégica.

Muitas empresas, principalmente as de ponta, reconhecem a importância da Comunicação e a tratam de forma integrada para construir relacionamentos positivos com seus diferentes públicos.

O gestor da comunicação organizacional, nesse cenário, deve criar espaços de relacionamento entre a organização e seus públicos de interesse, contribuindo para o cumprimento de sua missão e o alcance de seus objetivos.

O mundo globalizado exige um profissional que compreenda a comunicação de forma integrada, baseada na investigação e organização de dados como instrumentos de legitimação do planejamento estratégico, contribuindo para a construção de um novo paradigma da Comunicação Organizacional.

Como resposta a essas necessidades, o Curso de Gestão Estratégica em Comunicação Organizacional e Relações Públicas da ECA-USP surgiu há dez anos com a proposta de formar profissionais com visão diferenciada do mundo e dos relacionamentos, capazes de pensar em uma nova comunicação, tornando-se estrategistas dentro das organizações em que atuam.

Apesar de formada em Marketing, minha atividade profissional sempre esteve focada somente na Comunicação Organizacional, porém sem percebê-la dentro de uma gestão integrada No primeiro contato com o curso, logo no processo de seleção, surpreendi-me ao descobrir que a experiência prática que havia adquirido era, na verdade, na atividade de Relações Públicas, mesmo sem ter formação específica para isso.

Para mim, o Gestcorp representou a revelação de minha identidade profissional e o rompimento com a comunicação simplesmente instrumental. 